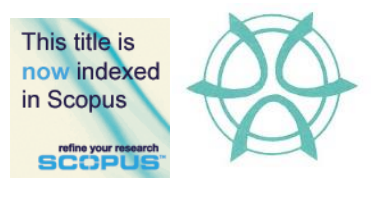

PLANNING MALAYSIA:

Journal of the Malaysian Institute of Planners

VOLUME 17 ISSUE 2 (2019), Page 101 - 111

\title{
EVALUATING CAPACITY BUILDING OF THE LOCAL COMMUNITY TOWARDS ENVIRONMENTAL CONSERVATION IN AN ESTUARINE COMMUNITY, KONG KONG LAUT, JOHOR
}

\author{
Faradiella Mohd Kusin', Amirul Azuan Md Joni², Ferdaus Mohamat Yusuff ${ }^{3}$, \\ \& Sharifah Nur Munirah Syed Hasan ${ }^{4}$ \\ ${ }^{1,2,3,4}$ Faculty of Environmental Studies \\ UNIVERSITI PUTRA MALAYSIA
}

\begin{abstract}
Key community-based environmental conservation programmes in Kong Kong Laut, Johor include the river and mangrove ecosystem conservation and management programme. The overall aim of conserving the ecosystem and encouraging local community participation in the programme is to promote the existing eco-tourism potential of the area. This paper entails the outcomes of community-based activities aimed at building the capacities of local communities through community mobilisation, awareness creation and capacity building (i.e. transferred knowledge and skills). Findings indicate that there have been improvements in the river water quality status within the ecosystems over the course of a one-year project, despite relatively small participation among the local communities in the conservation programme. However, it was evident that active participation from a minority group of the local community has contributed to significant human and social capital, suggesting that community empowerment might be crucial for future development. Despite this, a school outreach programme on waste minimisation within the community demonstrated an encouraging level of participation among school children and teachers. The major challenge to maintaining continuous efforts to conserve their environment is the simultaneous developments taking place close to the river and mangrove ecosystems. While it remains a challenge to all the stakeholders, collaborative efforts among the local communities and the university, school, government agencies and private sector have made it possible to strategise for more future approaches that will benefit the whole community.
\end{abstract}

Keywords: Knowledge transfer, environmental conservation, capacity building, local community, awareness, water quality 
Faradiella Mohd Kusin, Amirul Azuan Md Joni, Ferdaus Mohamat Yusuff, Sharifah Nur Munirah Syed Hasan Evaluating Capacity Building of the Local Community Towards Environmental Conservation in an Estuarine Community, Kong Kong Laut, Johor

\section{INTRODUCTION}

The role of university engagements in capacity building programmes has been undeniably important in helping to develop and strengthen the skills and abilities that communities need in order to adapt and thrive in a changing environment. Capacity building not only focuses on internal activities among students and university staff towards building their capacities, but rather, the focus has now extended to externally-oriented activities aimed at building capacity within a local community to promote engagement in a wider group of stakeholders. Universities may either lead such activities, or be the key partner in endeavours to empower communities in order to address challenges (Shiel, Filho, do-Paco, $\&$ Brandli, 2016). This will enable communities to develop sustainable ways of living through facilitation, community learning and continuous efforts to build their capacities.

This paper presents the processes and outcomes of community development and conservation programmes aimed at improving participation and building capacity in a local community. It assesses the extent to which the approaches have contributed to more sustainably-managed environments and increased awareness among the local communities through the transferred knowledge and skills.

The greatest challenge in the conservation and management of river and mangrove ecosystems in Kong Kong Laut, Johor comes from the simultaneous developments taking place close to the river ecosystem and the various anthropogenic activities along the coast. The mangrove ecosystem is very diverse in its composition and has become one of the main attractions of the local community in terms of eco-tourism potential. Therefore, such a conservation effort would essentially help in maintaining and sustaining the river and mangrove ecosystems' functions in the particular environment. This paper describes the experiences gained in the community-based programme in which the overall objective is the conservation and management of the river and mangrove ecosystems. In addition, involvement and active participation of local communities have been identified as key to integrating the diverse perspectives of the local communities (Raburu, Wa'Munga, \& Okeyo-Owuor, 2012).

\section{METHODS}

\section{Programme Planning}

The activities conducted throughout the conservation project were planned on a quarterly basis over a period of one year starting with community mobilisation, awareness creation and capacity building in an attempt to encourage full participation from the local communities. 
PLANNING MALAYSIA

Journal of the Malaysia Institute of Planners (2019)

\section{Approaches Used in the Conservation Programme}

\section{Community Mobilisation}

At the beginning of the project, community leaders and representatives were mobilised and brought for a tour within the river ecosystems to enable them to recognise environmental problems and the potential to improve existing ecotourism within the area. A focused-group discussion was then conducted where they discussed the causes of environmental problems, possible ways of mitigating the issues and strategies for future eco-tourism development in their local community. Members of the community were also mobilised and given the opportunity to visit other local communities having the same ecosystem characteristics as theirs. Apart from the community members, teachers from a primary school located in the project area were also involved in order to indirectly encourage participation among school children.

\section{Awareness Creation}

Awareness brings issues to the attention of individuals or key groups who have the power to influence outcomes (Stephen, Jai, Syma, \& Laly, 2000). According to Bahir (2010), a typical awareness-raising cycle includes, namely: capturing the attention of stakeholders and stimulating their interest; improving the public's knowledge and understanding; enhancing social skills and competencies for change; increasing capacity to implement change; and finally, implementing the change and evaluating progress made.

In order to attract maximum participation from stakeholders in the conservation programme, several approaches towards crafting awareness programmes and activities were carried out, as different approaches were targeted for different stakeholders (Figure 1). For instance, a two-day conservation and community service programme in the local community provided opportunities to create awareness to a wider group of stakeholders, including government officials, the private sector, school children, and the general public. In this programme, local communities were informed of the importance of environmental conservation so as to facilitate their understanding on the importance of maintaining sustainable environments.

Apart from this programme, the role played by the school in awareness creation through a school outreach programme was outstanding. Activities involving the school children were designed to create life-long awareness among the pupils and the general public. All activities conducted such as the waste minimisation and recycling programme were organised in the form of competitions among the primary school children and the general public (local communities of Kampung Sg Latoh and Kong Kong Laut). The theme for the competitions was set in accordance with the waste management programme, (i.e. From Waste to Solution). The best products from the waste minimization 
Faradiella Mohd Kusin, Amirul Azuan Md Joni, Ferdaus Mohamat Yusuff, Sharifah Nur Munirah Syed Hasan Evaluating Capacity Building of the Local Community Towards Environmental Conservation in an Estuarine Community, Kong Kong Laut, Johor

programme were awarded prizes so as to stimulate future participation and raise awareness among pupils.

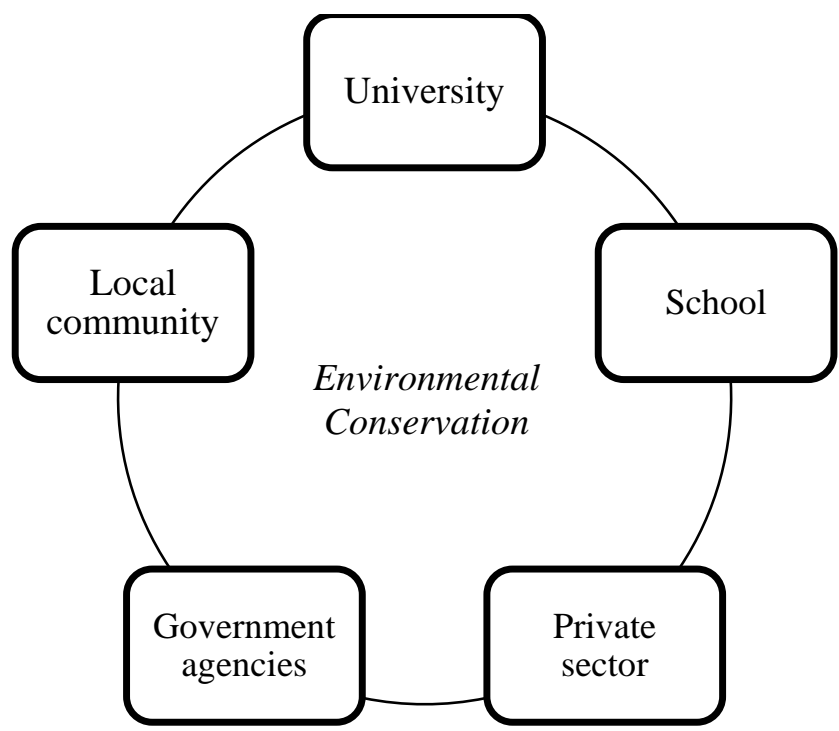

Figure 1 Involvement of stakeholders in the environmental conservation programme in Kong Kong Laut, Johor

\section{Capacity Building Programme}

Capacity building is designed to equip community members with skills that would enable them to mobilise resources even after they are left on their own. In addition to the transfer of knowledge and technical capabilities, capacity building should also foster social cohesion within communities and build both human and social capital (Raburu et al., 2012). Capacity building relates to a range of activities whereby individuals or groups improve their capacity in achieving sustainable natural resource management (FAO, 1999). The approach to community capacity building aims to ensure that it is an empowering experience for communities engaged in the development programme so that their capacity is sustained after the programme ends (Tania \& Daniel, 2003).

During the course of the project, training courses were conducted on, the following topics: techniques of river water quality monitoring; conservation of the river ecosystem and water resources; and minimisation of waste generation. These knowledge transfers were aimed at improving the local communities' skills in resource management and mobilisation. The activity crafted for achieving community engagement was specifically aimed at enhancing the ability to act through the provision of the transferred knowledge and skills, and fostering motivation to act through awareness creation programmes and support that lead to effective community engagement (Raburu et al., 2012). The local communities 
PLANNING MALAYSIA

Journal of the Malaysia Institute of Planners (2019)

were also motivated to develop their leadership skills. Apart from the community members, the university staff also benefited from the various aspects of the capacity building activities.

\section{Community Participation}

Participation of all stakeholders including the local community, university community, school community, government agency and private sector was measured by evaluating the number of actual participation from the targeted number of participants from each target groups. The degree of participation was denoted as having satisfactory or unsatisfactory involvement based on the number of actual participation ranked from low to high percentage of participation. Local community participation was further evaluated through a cross-sectional survey involving the local communities within the ecosystem to exemplify their awareness and satisfaction on the conservation programme as well as their willingness to participate in the capacity building programmes. The local communities were informed of the activities so that they were aware of the conservation programme.

\section{Monitoring Programme}

In order to ensure the effectiveness of this programme, continuous monitoring was carried out each month for one year. A field monitoring programme for observing the improvement of water quality was performed during the period April to December 2015. This was intended to assess whether any improvement had been made after the commissioning of the conservation programme starting November 2014. Monitoring of the water quality was undertaken at several locations (S1-S5) as shown in Figure 2. Description of the monitored locations is given in Table 1. Multiple activities that are taking place in the vicinity of the study area could directly or indirectly cause an impact on the quality of the river water (Kusin et al., 2017). As such, the conservation programme was centralised in the areas that are potentially affected by various activities within and nearby the river ecosystem. 
Faradiella Mohd Kusin, Amirul Azuan Md Joni, Ferdaus Mohamat Yusuff, Sharifah Nur Munirah Syed Hasan Evaluating Capacity Building of the Local Community Towards Environmental Conservation in an Estuarine Community, Kong Kong Laut, Johor

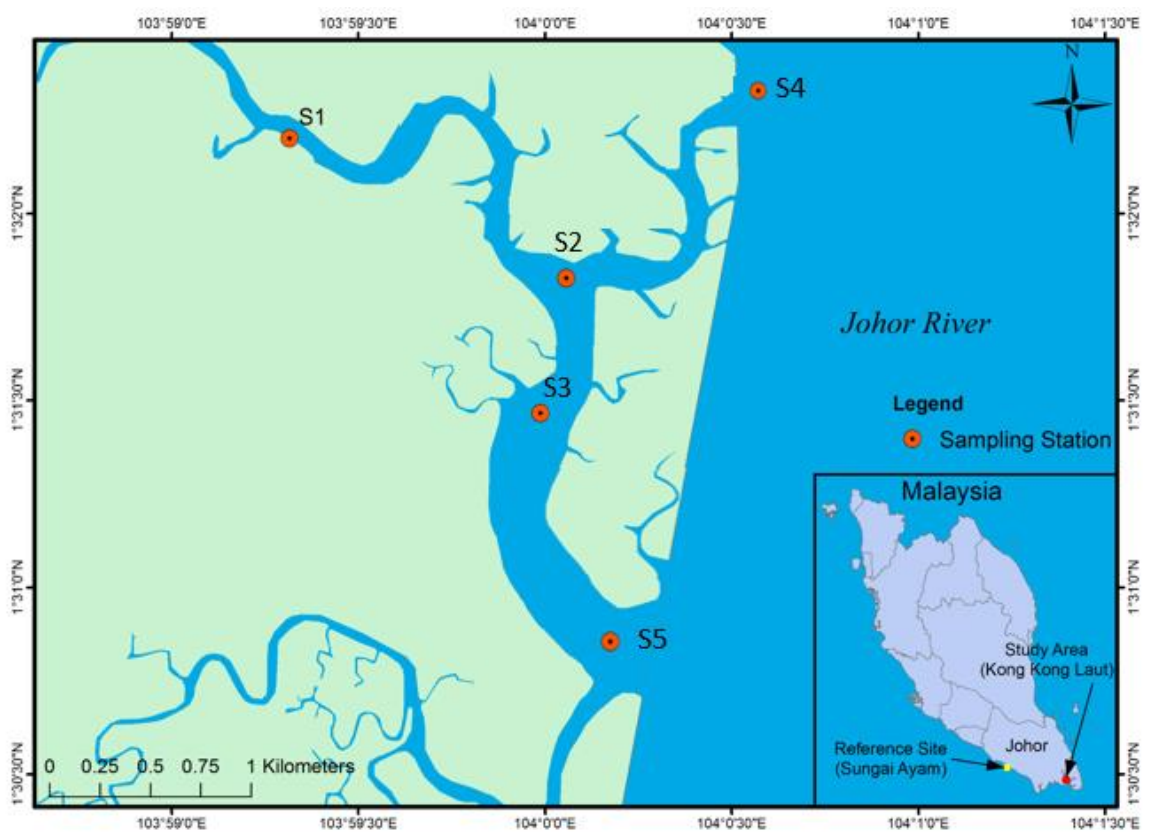

Figure 2 Locations of river water quality monitoring in Kong Kong Laut, Johor

Table 1 Description of monitored locations

\begin{tabular}{ll}
\hline Monitored Station & \multicolumn{1}{c}{ Site Description } \\
\hline Sg. Serai (S1) & $\begin{array}{l}\text { A tributary to Mendana Strait; near to oil palm plantation } \\
\text { areas }\end{array}$ \\
\hline Sg. Serai (S2) & $\begin{array}{l}\text { A tributary to Mendana Strait; fishing area and waterway } \\
\text { transportation }\end{array}$ \\
\hline Selat Mendana (S3) & Within raft house and jetty areas \\
\hline Selat Mendana (S4) & An estuary to Sg. Johor \\
\hline Selat Mendana (S5) & Within restaurant area \\
\hline
\end{tabular}

\section{RESULTS AND DISCUSSION}

\section{Capacity Building of Local Community}

The involvement of local communities in the conservation programme greatly contributed to maintaining and restoring ecological integrity and improving community well-being. In addition, it also helped to promote the area's ecotourism potential, as in the case of Kampung Kong Kong Laut. Although physical development of the community are clearly visible in terms of infrastructure development, there was still a lack of community participation in most of the capacity building programmes. This suggests that the physical development in the area are still not in line with the objectives of the conservation programme. 
PLANNING MALAYSIA

However, active participation from a minority segment of the local communities has been a great contribution. Despite the relatively small number of active participation, this group has contributed to significant growth of human and social capital within their community. Thus, this choice had indirectly created 2 groups of social capital within the local communities, namely, the uncooperative group and the cooperative group. Social capital can be defined as the social relationship of individuals or groups (Agnitsch, Flora, \& Ryan, 2006; Matarasso, 2007). It may facilitate transactions among groups of a particular interest, while excluding other groups from access to resources (Warren, Acciaioli, Steenbergen, \& McCarthy, 2015). The existence of the uncooperative group arises basically because they feel uncomfortable with outside interference as they are aware of the implications (Sudarmono, Sulehan, \& Bakar, 2012). One of the implications that usually eventuate is the lowering of their social status compared to the outsiders, who are viewed as having high status. Thus, they have to work hard to obtain more resources in order to achieve higher benefits. On the other hand, the cooperative group was willingly involved in the activities as their own motivation drove them to use the resources available for the benefit of the whole community.

As monitoring and data collection processes were continuous throughout the period of the project, it became evident that the uncooperative group not only had a fragile relationship with the cooperative group (even though they come from within the same community (bonding social capital)), but also with outsiders (linking social capital). In this case, the implication was other organisations. According to Woolcock \& Narayan (2000), linking social capital has a major influence on helping individuals or communities to gain power to control their lives in many aspects, including environmental circumstances within a community's living area. Furthermore, the new interventions made the uncooperative group feel threatened, especially when they were trying to maintain their existing lifestyles. The conflict occurred when there were interventions through specific regulations and mechanisms that attempt to interfere with the local community's daily practices. This is also one of the factors that may lead to the fragility of linking social capacity, which is influential to help a community gain access to other resources and thus, improve their quality of life (Woolcock \& Narayan, 2000).

\section{Local Community Participation}

The overall participation from stakeholders over the course of the programme is summarised in Table 2. Participants' involvement was ranked according to the percentage of participation from each groups; poor (0-25\%), low (16-50\%), moderate $(51-75 \%)$ and high $(76-100 \%)$. Satisfactory involvement denotes moderate to high participation from the targeted number of participants from each group. It was evident that participation from the local communities of $\mathrm{Kg}$. Sg. Latoh and Kong Kong Laut was still at unsatisfactory level. Therefore, the local 
Faradiella Mohd Kusin, Amirul Azuan Md Joni, Ferdaus Mohamat Yusuff, Sharifah Nur Munirah Syed Hasan Evaluating Capacity Building of the Local Community Towards Environmental Conservation in an Estuarine Community, Kong Kong Laut, Johor

communities were evaluated of their awareness on the conservation programme, satisfaction towards existing condition of the ecosystem, so as their willingness to participate in the capacity building programme.

Table 2 Summary of participation of stakeholders/target groups

\begin{tabular}{|c|c|c|}
\hline Stakeholder/target group & Role & Remarks \\
\hline $\begin{array}{l}\text { University (researchers and } \\
\text { students of Faculty of } \\
\text { Environmental Studies, } \\
\text { UPM) }\end{array}$ & $\begin{array}{l}\text { Project team / Programme } \\
\text { leader/ Facilitator/ } \\
\text { Demonstrator }\end{array}$ & $\begin{array}{l}\text { Satisfactory } \\
\text { involvement by all } \\
\text { members }\end{array}$ \\
\hline $\begin{array}{l}\text { Local community } \\
\text { (Communities of } \mathrm{Kg} . \mathrm{Sg} \\
\text { Latoh and Kong Kong } \\
\text { Laut) }\end{array}$ & $\begin{array}{l}\text { Permanent } \\
\text { residents/villagers }\end{array}$ & $\begin{array}{l}\text { Unsatisfactory } \\
\text { involvement }\end{array}$ \\
\hline $\begin{array}{l}\text { Local community } \\
\text { (members of Koperasi Kg } \\
\text { Sg Latoh Berhad) }\end{array}$ & $\begin{array}{l}\text { Initiator to community } \\
\text { infrastructure development, } \\
\text { managing the eco-tourism } \\
\text { sector }\end{array}$ & $\begin{array}{l}\text { Satisfactory } \\
\text { involvement by a } \\
\text { minority of active } \\
\text { members }\end{array}$ \\
\hline $\begin{array}{l}\text { School community } \\
\text { (primary school-SK Kong } \\
\text { Kong Laut) }\end{array}$ & $\begin{array}{l}\text { Teacher/educator } \\
\text { Pupils }\end{array}$ & $\begin{array}{l}\text { Satisfactory } \\
\text { involvement by all } \\
\text { members }\end{array}$ \\
\hline $\begin{array}{l}\text { Government agency } \\
\text { (IRDA) }\end{array}$ & Development funder & $\begin{array}{l}\text { Satisfactory } \\
\text { involvement }\end{array}$ \\
\hline $\begin{array}{l}\text { Private sector } \\
\text { (individual companies) }\end{array}$ & Service provider & $\begin{array}{l}\text { Satisfactory } \\
\text { involvement }\end{array}$ \\
\hline
\end{tabular}

The local communities included communities of Kg. Sg. Latoh and Kong Kong Laut, as well as members of Koperasi Kg. Sg. Latoh Berhad. This includes a range of communities aging between 20-70 years and having education background of between secondary school certificate and bachelor's degree holders. In terms of awareness creation, it was found that majority of the local communities were aware of the conservation programmes taking place within their ecosystem. However, more than half of them were having lower satisfaction towards existing riverine ecosystem conditions. This was mainly due to current physical development across their community that may hinder synchronised integration between natural resources management and rural development.

Despite having high intention to participate in the conservation programmes, the level of participation in the community was closely related with their social and economic needs. The older generation and members of Koperasi Kg. Sg. Latoh Berhad were the active participating communities because they were the initiator to the community infrastructure development and responsible for the eco-tourism sector within the community. They also believed that environmental conservation is equally important to physical and eco-tourism development that has long served as their main source of income. The younger 
PLANNING MALAYSIA

Journal of the Malaysia Institute of Planners (2019)

generation showed lesser extent of participation partly because they are less sure of their ability to contribute to such programmes and due to time availability.

\section{Factors Influencing Capacity Building on Environmental Conservation in a Local Community}

Factors that influenced the outcomes of the conservation programme in Kong Kong Laut based on local experiences with capacity building approaches are given in Table 3. These are summarised according to several basic principles, which must be put in practice for community-based natural resource management approaches (Addun \& Muzones, 1997).

Table 3 Factors that influence capacity building on environmental conservation in Kong

\begin{tabular}{|c|c|}
\hline \multicolumn{2}{|c|}{ Kong Laut } \\
\hline Influencing factor & Requirements for improvement \\
\hline $\begin{array}{l}\text { *Empowerment - the actual transfer of } \\
\text { economic and political power from the } \\
\text { operationalisation of community } \\
\text { management }\end{array}$ & $\begin{array}{l}\text { Wider cooperation between leaders and } \\
\text { organisation members is needed }\end{array}$ \\
\hline $\begin{array}{l}\text { *Sustainability - ensure development } \\
\text { through resource extraction practices, } \\
\text { intra-generational equity and equity } \\
\text { between present and future generations }\end{array}$ & $\begin{array}{l}\text { A systematic incorporation of the } \\
\text { conservation approach is needed to } \\
\text { bridge the gap between young and senior } \\
\text { members }\end{array}$ \\
\hline $\begin{array}{l}\text { *Equity - where communities as a whole } \\
\text { rather than only a few individuals benefit }\end{array}$ & $\begin{array}{l}\text { Attention is required to encourage } \\
\text { participation of marginalised groups }\end{array}$ \\
\hline Timeframe & $\begin{array}{l}\text { Interventions require longer time frames } \\
\text { to enable adaptive learning }\end{array}$ \\
\hline
\end{tabular}

\section{Partnerships in the Community Conservation Programme}

Partnerships in community-based programme are important in order to achieve sustained and continuous capacity building among all the stakeholders. Over the course of the project, several collaborative activities were carried out with collaboration among local communities, government agencies, the university and the private sector respectively. The activities included a series of workshops and awareness programmes such as: Awareness Campaign on Waste Management; Workshop on Pytoremediation Technique; Waste-to-Solution Competition; and an educational visit by the stakeholders. The major government agencies that worked closely with the project were the Iskandar Regional Development Authority (IRDA) and the Department of Fisheries, Johor. IRDA is a Malaysian Federal Government statutory body responsible for regulating and fostering stakeholders' involvement towards sustainable development within Iskandar Malaysia. The project also benefitted from contributions by private companies that have helped in enhancing and promoting the eco-tourism potential of the village. 
Faradiella Mohd Kusin, Amirul Azuan Md Joni, Ferdaus Mohamat Yusuff, Sharifah Nur Munirah Syed Hasan Evaluating Capacity Building of the Local Community Towards Environmental Conservation in an Estuarine Community, Kong Kong Laut, Johor

\section{CONCLUSION}

A sustained and successful conservation programme requires a good relationship between both the bonding social capital and influential linking social capital. This reflects the potential for an effective transfer of knowledge and skills. It is crucial that such a relationship would improve in various aspects, thus enabling them to attain better capacities of life in facing challenges. Experiences gained from the community-based programme have exemplified significant roles from all stakeholders involved, although continuous efforts will still have to be made to stimulate full participation among local communities. Community sustainability was seen as an important tool to facilitate wider cooperation among the local public, as it was evident that they do have the capacity to further develop their areas by integrating natural resources. This is clearly in line with the overall objective of the conservation programme, despite having to face changing environments as a result of current physical developments across their community.

\section{ACKNOWLEDGEMENTS}

The authors would like to thank the University Community Transformation Centre (UCTC) of Universiti Putra Malaysia for providing the financial support for the project through the Knowledge Transfer Grant Scheme (KTGS) grant no: KTGS/9437505 and the Ministry of Higher Education Malaysia through the grant FRGS/5540081. Thanks are also due to all the community members of Kong Kong Laut, Johor and Koperasi Kg. Sg. Latoh Berhad for the direct and indirect support of the project.

\section{REFERENCES}

Addun, R. P. \& Muzones, D. M. (1997). Community-based coastal resource management (CBCRM): Tambuyog's experience in the Philippines. In G. F. Claridge, \& B. O'Callaghan (Eds.), Community involvement in wetland management: lessons from the field (pp. 219-230). Kuala Lumpur: Wetlands International.

Agnitsch, K., Flora, J. \& Ryan, V. (2006). Bonding and bridging social capital: The interactive effects on community action. Community Development, 37(1), 36-51.

Bahir, D. (2010). Sensitization and awareness raising strategy Tana-Beles WME Reports. Orgut \& Niras No 11: 24 pp.

FAO. (1999). Incentives systems for natural resources management: The role of indirect incentives. Report No. 99/023 IFAD-RAF.

Kusin, F. M., Rahman, M. S. A., Madzin, Z., Jusop, S., Mohamat-Yusuff, F., Ariffin, M., \& Zahar, M.S.M. (2017). The occurrence and potential ecological risk assessment of bauxite mine-impacted water and sediments in Kuantan, Pahang, Malaysia. Environmental Science \& Pollution Research, 24(2), 1306-1321.

Matarasso, F. (2007). Common ground: Cultural action as a route to community development. Community Development Journal, 42(4), 449-458.

Raburu, P. O., Wa'Munga, P. O., \& Okeyo-Owuor, J. B. (2012). Experiences from community participation in managing Nyando Wetland, Lake Victoria Basin, 
Kenya. Nairobi, Kenya: Kenya Disaster Concern - VIRED - UNDP.

Shiel, C., Filho, W. L, do-Paco, A., \& Brandli, L. (2016). Evaluating the engagement of universities in capacity building for sustainable development in local communities. Evaluation and Program Planning, 54, 123-134.

Stephen, R. K., Jai, N. M., Syma, A. E., \& Laly, L. L. (2000). Community natural resource management: Promise, rhetoric, and reality. Society and Natural Resources, 13, 705-715.

Sudarmono, Sulehan, J., \& Bakar, N. R. A (2012). Patron-client relationship of urbanized fishing communities in Makassar. International Journal on Social Science, Economics and Art, 2, 1-5.

Tania, M. S., \& Daniel, J. D. (2003). Social learning for collaborative natural resource management. Society and Natural Resources, 15, 309-326.

Warren, C., Acciaioli, G., Steenbergen, D., \& McCarthy, J. (2015). Social capital formation in community development and conservation interventions: Comparative research in Indonesia. Brief for GSDR 2015.

Woolcock, M., \& Narayan, D. (2000). Social capital: Implications for development theory, research, and policy. World Bank Research Observer, 15(2), 225-250

Received: $12^{\text {th }}$ January 2019. Accepted: $2^{\text {nd }}$ August 2019 